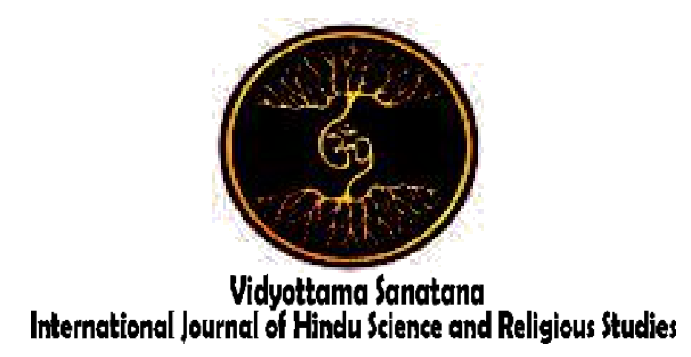

Vol. 3 No. 2 October 2019

\title{
THE INFLUENCE OF TARKAŚĀSTRA PROFICIENCY IN THE INTERNAL AND INTERFAITH DIALOGUE NOWADAYS
}

\author{
By: \\ Ni Kadek Surpi \\ Institut Hindu Dharma Negeri Denpasar \\ E-mail : dosen.surpiaryadharma@gmail.com
}

\begin{tabular}{|l|l|l} 
Received: August 11, 2019 & Accepted: September 18, 2019 & Published: October 31, 2019 \\
\hline
\end{tabular}

\begin{abstract}
Proficiency in Tarkaśāstra, philosophy, and theology dramatically influences the ability to run dialogue both internally and between religious communities. Besides that, the ability to think critically and established arguments, dialogue, debate, and discussion are the central knowledge in darśana. Hindu thinkers master the Tarka-Väda and can dialogue with followers of Sanatana Dharma and other believers. The expertise of Ādi Śankkarācārya and other Hindu thinkers in the field of Tarka-Vāda is essential today in the Dharmapracāraka, teachers, Hindu intellectuals, academics, and Hindu devotees. Also, the mastery of the TarkaVada as an effort to support the science of communication (Vakya Vidya) in the Hindu tree of knowledge and glorify Vācaspati.
\end{abstract}

Keywords: Philosophy, darśana, Dialogue, Tarkaśāstra, Tarka -Vāda, Dharmapracāraka

\section{INTRODUCTION}

Today, Hinduism in Indonesia, even in the world, is facing attacks from preachers of other religions. Various topics in Hinduism are compared blindly with several lecturers to denigrate Hinduism and show the faith they profess. Likewise, dialogue and debate cannot be avoided, especially on social media platforms (social media). Social media users, regardless of their background and free knowledge of dialogue, even mock each other and slander the teachings of others with no guilt. In addition, it has become a daily routine for young people to search for various topics using a web search engine. Hindus with a pattern of religious learning that tends to be natural and passive seem desperate when other people question various Hindu teaching topics. It appears that they are not ready and unable to dialogue, 
discuss, or even argue. In fact, in the Hindu Suśāstra, debate and discussion are fundamental knowledge to be studied first by Dharmapracāraka (Hindu Lecturer, teacher). Hindu civilization has experienced attacks several times, and there have been changes, such as the onslaught of the birth of Buddhism, Jaina, Islam, Christianity, and the incursion of modernity.

To face the challenges of modernity in this contemporary era, Hindus should redesign strategies following the challenges of the times. The use of IT and Social Media is very massive and the emergence of lecturers who continue to attack various Hindu teachings and even declare themselves as people who understand the contents of the Vedas make many young people experience confusion about their religion. The study of Hinduism should shift from using traditional patterns to the jñāna path, in the form of learning of Holy Literature, philosophy, and theology.

A scholar is required to master the various arts of communication, including discussion and debate. Dharmapracārakas, Hindu devotees, organizational leaders should comprehend the Tarkaśāstra (logic, debate, and debate) well. Therefore, it is where the biggest weakness of Hinduism laid. The fact that most of the people who are supposed to master the Tarkashastra, but lack this knowledge. Scholars, teachers, lecturers, Dharmapracāraka, Hindu religious instructors, PHDI administrators, administrators of Hindu organizations, Dharma Ambassadors, and also Ministry of Religion employees should master the science of public speaking, communicate well and be able to debate/discuss. Because the Vedas say that the successors of truth, orators play a significant role in the transformation of society.

Hindu thinkers have long recognized that Śruti and Śāstra are closely related to Śraddhā or faith. Thus the aim of Śāstra's learning is to strengthen the beliefs of Hindus and be able to communicate them with the community. Today, human reasoning wants to be satisfied with knowledge. Thus, Śruti and Śāstra were the answers, aided by the science of reason and logic and excellent communication skills. Darśana, Hindu Philosophy, and Theology (Brahma vidya) are studied through Śruti and Śāstra to strengthen Śraddhā. In addition, the power of reasoning, communication skills will be increased through intensive learning in order to open a path of dialogue both internally and between religious communities

\section{METHOD}

This study is a text study that examines the values and ideas of Tarkasastra In Hindus Ancient text such as Upanișad Bhagavata Purāna Bhagavad Gìtā, Garuda Purana, Sushruta Samhita, Abhinayadarpana, Vedanta Sutra. This research focused on how the values Tarkasastra can be used as a basis in discussion and debate today

This study uses the Paul Ricoeur Interpretation Theory. In his theory, Paul Ricoeur seeks to bridge the problem of discourse that has been going on for a very long time and has become a problem by Plato and Aristotle. Ricoeur started his discussion with the theme of language as a discourse. Ricoeur says (2012: 18) this is the first context in which the concept of discourse is known, that mistakes and truths are the affection of discourse and discourse to establish two basic signs, one noun and one interrelated verb in the synthetic form (meaningful) behind the well said word. Furthermore, Ricoeur stated (2012: 19) in this modern linguistics, the problem of discourse becomes an original thing because today's discourse can be contradicted by a contradictory term which unknown or not justified by ancient philosophers.

\section{RESULTS AND DISCUSSION}

Dialogue holds an essential place in the Hindu Suśāstra. Hindu texts-Śruti and Śāstra are full of dialogue to convey various teachings. The Upanișad scriptures are full of conversation. Even the most famous scripture of the Bhagavad Gîtā is the 
dialogue between Śri Krṣnạa the Lord of Yoga and Arjuna the mighty hero and great archer. Likewise, various suśāstra use discussion as a medium to convey various teachings. Dialogue in the Hindu tradition is believed to have been very old, which developed in multiple forms.

Dialogue also plays a vital role in Vaișnava's tradition and vision. First, the dialogue itself is an integral part of the practice and worship of life that is applied in Krș̣nā bhakti. Dialogue is also the sāastra matrix through which even the most significant revelations of Kṛṣnā's divine actions are most frequently expressed. Moreover, the dialogue is a pedagogical medium through which the holy teachings are transmitted. And finally, the conversation becomes a fundamental and essential element in the most intimate exchanges between the divine figures in līlā contained in the holy realm (Schweig, 2012:51). Dialogue is an essential thing that even cannot be avoided today. In the world, the Vaisnava community plays a critical role that builds a bridge of dialogue between the Sanatana Dharma and other religions. But actually, this dialogue was pioneered by Swami Vivekananda when he attended the Parliament of the World Religions in Chicago, September 11, 1893.

Dialogue, debate, and discussion are nothing new in the Hindu tradition. Even Hindu literature is dialogue, primarily Upanisad and Bhagavad Gìtā. Dialogue is the dominant expression mode in these texts. As we often speak of the Socratic dialogue, we might also talk of the Upanishad dialogue. Because the Upanishads, especially the early ones, are filled with educational dialogue between teachers and students. The famous Bhagavad Gìtā is dialogue, conversation, between Kṛșnā and Arjuna, originating from within the outer narrative dialogue layer between Dhritarāshtra and Sanjaya. It is not uncommon to find multilayered discussions within the narrative frame of Sanskrit epic and historical texts. For example, the Like with Parīkșit dialogue, which took place at the Bhagavata Purāna, is told in a conversation between wise men from the Naimiśa forest (Schweig, 2012:51). Besides, the text of the Bhagavata is filled with various dialogues. Even Upadesa books compiled in Bali use discussion as a learning medium.

Schweig (2012: 61) states in the Vaișnava tradition, the dialogue is considered to be the Dance of Divine Love called Rāsa. The five chapters of the Bhāgavata known as Rāsa Līlā are rich in dialog symbolism, this final symbol of union in the divine love-Rāsa Mandala. The dance begins with the Gopikā Vraja, the cowherd girls from Vraja, who connect weapons to form a large circle of dancers around the divine figure of Krșnāa who remains at the center of the maṇdala. Then Kṛṣnā is the one who multiplies his divine form as many times as needed to enter between each of the two Vraja Gopikās. The significance of Krṣnāa comes between the two Gopikas, whether this: the two partners in dialogue have the power to attract new presence or divine revelation. Which is the fourth phase of axial dialogue must be considered the perfection of dialogue. The symbols of Rāsa Mandala can be seen and interpreted as symbols of great discussion, the building blocks of authentic pluralism. At the very least, he can speak to Vaiṣnava as a symbol of the perfect form of dialogue or sharing between humans and the divine, and also between humans and other humans.

Hinduism never really opposes dialogue, but instead teaches dialogue as an effort to enlighten each other, mutual Enlightenment (Kathāa, parasparam), as the Bhagavad Gītā sloka says:

mac-cittā mad-gata-prāṇā
bodhayantah parasparam
kathayantaś ca mām nityam
tușyanti ca ramanti ca
Bhagavad Gītā X.9

With their minds focussed on Me, with their prānas centred in Me, inspiring one another and always speaking of $\mathrm{Me}$, 
they live in contentment and bliss at all times (Rāmānuja, 2009:333)

The Bhagavad Gìtā translation of Rāmānuja is the oldest bhașya (commentary) after Śankarācārya. Schweig (2012: 57) states that there are four activities related to devotion described in the verse. (1) The first quarter of this verse directs one to enter deeper into a personal relationship with the divine, by focusing all one's thought processes on divine and offers one's breath of life to the divine (maccittā mad-gata-prānāā). (2) The second part explains what others can do, with the phrase "enlightening one another" (bodhayantah parasparam). (3) The third quarter of this verse talks about how this shared enlightenment between souls becomes a fully absorbed kathā or continuous conversation about the divine (kathayantaś ca mām nityam). (4) And the last line describes the satisfaction and affection one feels in sharing in this devotional service.

In Hindu literature, about 246 books were found containing Tarka Śāstra, such as the Garuda Purana, Sushruta Samhita, Bhagavata Purana, the Abhinaya-darpana (the mirror of gesture), Vedanta Sutra and hundreds of other books. Thus the science of debate and discussion is a fundamental knowledge since ancient times and is widely used in Darsana. A very famous Tarka is the Tarka between Śankarācārya and the Mandana Miśra in Mahismati (now Mahishi Bangaon, Saharsa in Bihar, India). Mandana Miśra is a very famous philosopher and teacher of the famous Mimamsa philosopher - Kumarīla Bhatța. When Kumarīla Bhatța met Śankkarācārya in Prayag, he suggested Śankkarācārya go to Mahismati to debate with the Mandana Miśra.

Acting as a jury is the wife of Mandana Miśra herself, namely Ubhaya Bhāratī, who is also an expert. The debate lasted more than fifteen days, and Mandana Miśra was declared defeated. Ubhaya Bhāratī then challenged Śankkarācārya to debate with him so that his victory was complete. Later
Ubhaya Bhāratī acknowledged his defeat, and as a consequence, Mandana Miśra and his wife became followers of Sankaracarya and were initiated under the name Sureśvarācārya.

Tarka Śāstra is a science of dialectics, logic and reasoning, and art of debate that analyzes the nature and source of knowledge and its validity. Sāstra in Sanskrit means that which gives teaching, instruction or command. Tarka means debate or an argument. Tarka is a method of attaining knowledge of the truth about an unknown thing by comparing and then gradually eliminating all the competing suppositions (Achari, 2013).

So Tarka Sāstra is the science of dialectics, logic and reasoning, and the art of debate that analyzes the nature and source of knowledge and its validity. In Sanskrit Language, Tarka means debate or argument. Tarka is a method of achieving an understanding of the truth about the unknown by comparing, discussing, and then gradually eliminating all other assumptions. So Tarka means also comparing one truth and another truth and analyzing it carefully, in detail and progressively to erase all doubts or contradictions in order to clarify the truth or find actual knowledge.

Vāda means discussion, which is the art of exchanging ideas, knowledge, and truth with others, intending to arrive at the truth. That can be achieved by discussing one topic with a sincere truth seeker. Achari (2013) states the purpose of Discussion is to arrive at the truth of the proposition under consideration. This may be achieved by talking about the topic with anyone who is a sincere seeker of Truth. The words Tarka and Vāda are often combined as Tarka-Vāda, which indicate the debate and discussion used to achieve truth.

The science of debate and discussion is critical in Hinduism and has been studied since ancient times. Hindu saints own the 
ability of debate and discussion to contemporary Hindu figures. In the development of Hindu philosophy, a number of notable people who were experts in Tarka were born, among them, Adi Sankara (788$820 \mathrm{CE}$ ), Uddyotkar (Nyāyavartik, 6th-7th century), Vācaspati Miśra (Tatparyatika, 9th century),

Udayanacharya

(Tatparyaparishuddhi, 10th-century) ), Jayanta Bhatta (Nyāyamanjari, 9th century), Vishwanath (Nyāyasutravrtti, 17th century), Radhamohan Goswami (Nyāyasutravivaran, 18th century) and Swami Vivekananda (12 January 1863-4 July 1902). Śankkarācārya is a very famous Tarka expert. Śankkarācārya was able to bring back thousands of people who had previously turned to return to the bosom of Sanatana Dharma. Śankara is renowned as a genius since young.

Swami Vivekananda was a young monk, famous for his speech in the parliament of world religions on September 11, 1893. During his work in the West, he was not uncommonly opposed because he brought a spirit from the East that was different from Christian mind or materialism. However, with his expertise which argued very subtly, he was able to conquer western materialism. As the first Hindu swami to go to the West and penetrate the Western wall of self-satisfied Christians, Swami Vivekananda is the national and international voice of the spiritual teacher Ramakrishna. $\mathrm{He}$ is an energetic and calm young man, athlete, and scholar. This university-educated rationalist almost ruled out God as inevitable human creativity when he met Sri Ramakrishna. In 1893 Vivekananda left for America on a steamboat to attend the Parliament of Religions in Chicago where he was not invited to this meeting.

Long ago, students went to Navadvipa in Bengala to study Tarka-Śāstra. In Bengala, many experts have mastered this knowledge, one of which is Gangeśa Miśra. Gangeśa Miśra returned to Bengala in the 12th century to regrow Nyāya Śāstra which very strongly known as "Navya Nyāya" meaning New Nyāya. Navadvipa is a place in Bengala where Gangeśa Miśra and his followers resided, and Sri Krishna Caitanya also came from this place. He was also a highly educated man, who mastered all Śāstra, then chose to repeat the name Krishna as the Bhajans of Sankirtan. After that, he and uphold the belief that singing the names of God is the way to attain liberation or moksha (Maswinara, 1999: 153). Sri Caitanya is famous for his philosophy ACintya Bhedabheda and is a great thinker in Vaisnava philosophy.

As such, the Tarka-Vāda requires good Śāstra mastery, Bible study, ability, and clarity of sight and good intelligence. Tarka in the intellectual level must not develop into a lie. It should instead be a debate to obtain the truth. Tarka is done by comparing one truth with another reality, the truth understood by one person with the debate opponent. This process is carried out without rejection of the views of others. But through serious discussion and debate to obtain or confirm the truth. High intelligence is needed to reason and understand something so that Tarka does not develop into a poor debate. Discuss using sharp and gentle knowledge and reason, not using ego, emotions, or just wanting to contradict each other.

A scholar is required to master the various arts of communication, including discussion and debate. Dharmapracharakas, Hindu devotees, leaders of the organization should have mastered Tarkaśāstra well. The biggest weakness of Hinduism is where most of the people who are supposed to master the Tarka but lack this knowledge. Scholars, teachers, lecturers, discourses of discourse, Hindu religious instructors, PHDI administrators and administrators of Hindu organizations, Dharma ambassadors, employees of the Ministry of Religion should master the science of public speaking. They have to communicate well and be able to debate/discuss because the Vedas say that the successors of truth, orators play a significant role in the transformation of society. The Vedic Scriptures state: divakșaso agnijihvā ṛtāvrdhah rgveda X.65.7 
"The teachers are the spreaders (successors) of truth, the orator who is bright and holy is like having a divine body. (Titib, $2006: 431$ ).

Religion does not kill the intellect or perspicacity, instead, a high intellect ability will actually sharpen the knowledge as stated Rigveda VIII.15.7 follows:

\section{Vajram śiśāti dhiṣaṇā vareṇam}

"The intellect sharpens sparkling knowledge like thunders (lightning). " (Titib, 2006 : 433).

Thus, intellect, the ability of the ratio is essential because it will sharpen knowledge. In its history, Tarka-Vāda is used to confirm the truth and even to protect civilization. The many spiritual teachers and intellectuals who master the Tarka will inspire the community and help in understanding the truth so that the community remains firm in its beliefs and Dharma. In the history of the Hindu archipelago and in Bali, not a few cases of religious conversion that occur because of losing debate about their faith. Where the scholars, missionaries are equipped with the science of disputes and affect the minds of others well to accept the religious truth or beliefs that it carries.

The Vedas state that scholars should exceed the abilities of others, be intelligent, shine (because they develop noble qualities), be wise like Gods, spread knowledge, emit waves of purity, build understanding, carry out religious ceremonies, have insight into the future, develop noble deeds and wise (Titib, 1996: 440). Scholars should always have and develop intelligence, glory, able to get rid of bad qualities and work for the prosperity of society. Intellectual ability is highly emphasized in the Vedas which must be possessed by scholars to understand the store of knowledge and wisdom thoroughly. So in Hinduism, it does not blindly accept truth as God's truth but instead develops an intellect to understand things better. Yajur Veda XXV.15 states "devānāim bhadrā sumatir rjūyatām- May we obtain the intellectual intellect of the noble Gods, for our well-being."

A scholar, a scholar is required to be skilled at communicating and understanding the meaning of conversation as stated by Rigveda IX.87.3:

sa cid viveda nihitam yad āsām apīcyai் guhyai் nāma gonām Rgveda IX.87.3

"A scholar knows the secret (meaning) of conversation."

Besides that, not just understanding knowledge and secret of conversation, an intellectual must also be able to have a third eye of knowledge, meaning to understand the most secret of knowledge.

Tṛtīyena jyotișā sam viśasva

Rgveda X.56.1

"O mankind, have the third eye of that knowledge."

Debate and dialogue are inevitable today, both formal and informal. Not infrequently debate and discussion can undermine one's faith. Donder (2006: 2), Surpi Aryadharma (2011: 126) outlines three crucial events of the theological debate, which ended with a loss of belief in Hinduism. First, Raja Majapahit (Brawijaya V) was unable to carry out a religious dialogue with Sunan Kalijaga, which led to the conversion of religion to Islam. Secondly, several sources indicate that King Buleleng A.A Pandji Tisna was unable to serve or win a theological debate with the zendeling. Therefore, he converted to Christianity and founded a church. The third defeat of the debate and supernatural fighting between the Leader of Leak with a missionary became the history of the emergence of Christianity in Buduk, Dalung, and Untal-Untal, in Badung Regency, Bali. Also, the historical event of the collapse of the Kutai Kertanegara Hindu kingdom into the Islamic empire was marked by the conversion of the King's Islam after losing 
the debate with the propagators of Islam. Two missionaries from the land of Bugis visited raja Makota Mulia Alam who ruled around the 14th century. They are Sheikh Yusuf or Mr. Tuanggang Parangan and Abdul Kadir Chatib or Mr. Di Bandang. The king was challenged to have a theological debate about the truths held by the King and his people compared to the teachings of Islam, continued with a magic battle. Furthermore, if the King is defeated, he and his entire kingdom were willing to convert to Islam. The king finally lost, and the Hindu kingdom was transformed into an Islamic sultanate. In the 16th century, the kingdom attacked the Kingdom of Kutai Martadipura located in Muara Kaman (Kutai Mulawarman). King Kutai Martadipura, Dharma Setia, as his name died as a Hindu (Aryadharma, 2011: 34)

Therefore, Tarka-Vāda should be the learning of every Hindu University, Hindu Organization, Hinduism study, material in the formulation of Hindu regeneration, preparing Dharma Hindu Ambassadors, Dharmapracharaka or future leaders of Hindu organizations. Because this knowledge is fundamental to explain and maintain the Dharma. The ability to explain is essential and the awareness to get out of the trap of opposing doctrines that only aims to defeat is equally crucial.

As Śañkarācārya traveled around with the Dharma mission, Dig-Vijaya (missionary tour) after defeating the Mandana Miśra, debating and propagating Advaita Vedanta, scholars should learn this skill. The service of Śañkarācārya is extraordinary in returning pride to the religion of the Dharma. Śankkarācārya also defeated the debates of Jainists in discussions at a place called the Bahlika. Śankkarācārya also confirmed his victory in the debate over several philosophers and ascetics in Cambodia (the Northern region of Kashmir), Darada (Dabistan) and against many of the beliefs found in the desert area and crossing the mighty summit into Kasmir. Śañkarācārya also met the Navagupta Tantric expert at Kamarupa. Ādi Śañkarācārya visited
Sarvajñapīṭa (Sharada Peeth) in Kashmir (now in Pakistan-Kashmir). The Shankaravijayam Madhaviya State temple has four doors for scholars from the four cardinal directions. The south door (representing South India) was never opened, indicating that no South Indian expert had entered the Sarvajna Pitha. Ādi Śankarācārya opened the south gate by defeating in the debate of all experts in all academic disciplines such as Mimamsa, Vedanta and other branches of Hindu philosophy. He ascended to the temple's Transcendent wisdom throne. Near the end of his life, Âdi Śankarācārya continued his journey to the Himalayan region of Kedarnath-Badrinath and attained Videha Mukti (freedom from manifestation).

It is the duty of scholars, scholars, especially scholars/masters of Hindu Philosophy to master the expertise of Ādi Śankarācārya and these other saints. With proper knowledge and mastery of the TarkaVāda, it will be advantageous not only for the sake of dialogue with other people but to convince one's people of the truth of their religious teachings. So far, this point is weak. Namely, the lecturers have not been able to convince the truth and have not been able to express well to the broader community to encourage transformation in society. The role of intellectuals is enormous and builds a society in all fields. But the mastery of Śāstra, theology, and philosophy should be an absolute requirement for dialogue, even discussion, and debate.

The ability of dialogue, debate, and discussion can be learned more efficiently as a tool in communication. However, what is the use of place/tool and without content? It contained the authority of Hindu Philosophy and Theology. This knowledge must be studied diligently and structured to mature one's experience. Tarka-Vādin, the Tarka expert, not only possesses excellent debating and logical abilities but begins with the mastery of Śruti and Śāstra so that he can uphold Śraddhā. Therefore, studying Praștana-trayā, namely Upanișad, Bhagavadgitā, and Brahma-Sūtra, was the primary 
gateway and continued with specific discussions on Hindu philosophy and theology. It requires in-depth knowledge and excellent communication skills to be able to dialogue both internally within Hindus and between religious communities, to explain various Hindu concepts and teachings that are often misunderstood.

\section{CONCLUSION}

Indian intellectual traditions were so advanced even when the beginning of the first millennium. Various types of knowledge such as Tarkaśāstra (reasoning science, the science of debate), Tarka-Vidyā (the science of reasoning), Vāda Vidyā (the science of discussion) and Ānviksiki (critical study), as essential aids in studying philosophy. We should inherit this tradition as a significant advantage in the 21st century. Debate and dialogue are inevitable today, both formal and informal. Not infrequently debate and dialogue can undermine one's faith as happened in Hindu historians in the archipelago.

Therefore, Tarka-Vāda should be the learning of every Hindu University, Hindu Organization, Hinduism study, material in the formulation of Hindu regeneration, preparing Dharma Hindu Ambassadors, Dharmapracharaka or future leaders of Hindu organizations because this knowledge is vital to explain and maintain the Dharma. The ability to explain is essential and the understanding to get out of the trap of opposing doctrines that only aims to defeat is equally crucial.

As Śañkarācārya traveled around with the Dharma mission, Dig-Vijaya (missionary tour) after defeating the Mandana Miśra, debating and propagating Advaita Vedanta, scholars should learn this skill. The service of Śankkarācārya is extraordinary in returning pride to the religion of the Dharma. Śankarācārya also defeated the debates of Jainists in debates at a place called the Bahlika. Śañkarācārya also confirmed his victory in the discussion over several philosophers and ascetics in Cambodia (the Northern region of Kashmir), Darada
(Dabistan) and against many of the beliefs found in the desert area and crossing the mighty summit into Kasmir. Śañkarācārya also met the Navagupta Tantric expert at Kamarupa. The younger generation of Hindus should be structured to be taught Philosophy and Theology, accompanied by excellent communication skills. So that the Hindu communication command, the knowledge of speech (Vakya Vidya) was increasingly developed so that Vācaspati, God as the ruler of speech, the Vedic Venerator was revered.

\section{REFERENCE}

Aryadharma, Ni Kadek Surpi.,2011. Membedah Kasus Konversi Agama di Bali. Surabaya : Paramita.

Aryadharma, Ni Kadek Surpi., 2012. Hindu di Tanah Bugis. Surabaya : Paramita.

Dās, Rāsamaṇḍala. 2014. Islam and the Vedas. India: Blue Lotus.

Dās, Rāsamandala. 2015. Revelations: Judaism Vedas Islam \& Christianity. India Blue Lotus.

Kangle, R.P. 1986. The Kautilya Arthasastra, Part 3, no. 14, Motilal Banarsidass Publ., 1986. p. 250

Ricoeur, Paul, 2012, Teori Interpretasi: Memahami Teks, Penafsiran dan Metodologinya, IRCiSoD, Yogyakarta.

Satchidānandendra, Sri Swami. 1989. The Method of the Vedanta: A Critical Account of the Advaita Tradition. Delhi: Motilal Banarsidass Publishers Private Limited.

Schweih, Graham M., "Vaishnava Bhakti Theology and Interfaith Dialogue. " Journal of Vaishnava Studies, Spring 2012, pp. 51-68

Vidyabhusana Mahāmahopādhyāya Satis Chandra., 1920. A History of Indian Logic Ancient, Mediaeval and Modern School. Delhi Patna Varanasi : Motilal Banarsidass. 